\title{
REVIEW
}

\section{Inter-relationships of haplosporidians deduced from ultrastructural studies}

\author{
P. M. Hine ${ }^{1,4, *}$, R. B. Carnegie ${ }^{2}$, E. M. Burreson ${ }^{2}$, M. Y. Engelsma ${ }^{3}$ \\ ${ }^{1}$ Investigation and Diagnostic Centre, Biosecurity New Zealand, Ministry of Agriculture and Forestry, PO Box 40-742, \\ Upper Hutt 6007, New Zealand \\ ${ }^{2}$ Virginia Institute of Marine Science, College of William and Mary, PO Box 1346, Gloucester Point, Virginia 23062, USA \\ ${ }^{3}$ CIDC-Lelystad, Centraal Veterinair Instituut, Postbus 65, 8200 AB Lelystad, The Netherlands
}

${ }^{4}$ Present address: 73 rue de la Fée au Bois, 17450 Fouras, France

\begin{abstract}
We reviewed papers reporting haplosporidian ultrastructure to compare inter-relationships based on ultrastructure with those based on molecular data, to identify features that may be important in haplosporidian taxonomy, and to consider parasite taxonomy in relation to host taxonomy. There were links between the following: (1) the plasmodia of an abalone parasite, Haplosporidium nelsoni and Urosporidium crescens in the release of haplosporosomes; (2) H. costale and H. armoricanum in haplosporosome shape and presence and shape of Golgi in spores; (3) basal asporous crustacean haplosporidians which form haplosporosomes from formative bodies (FBs) in vegetative stages $-H$. nelsoni, which forms haplosporosomes from FBs in plasmodial cytoplasm, and H. louisiana, Minchinia spp. and Bonamia perspora, which form haplosporosomes from FBs in spores; (4) crustacean haplosporidians, Bonamia spp. and M. occulta in the predominance of uni- and binucleate stages; and (5) lipid-like vesicles in sporoplasms of $H$. costale, $H$. armoricanum, $H$. lusitanicum, $H$. pickfordi, $H$. montforti, and B. perspora. In general, these relationships reflect phylogenies based on molecular studies. As well as spore form and ornamentation, haplosporogenesis in spores appears to be taxonomically important. Parasite and host taxonomy were linked in the infection of lower invertebrates by Urosporidium spp., the infection of oysters by Bonamia spp., and of molluscs by Minchinia spp. Haplosporidium spp. are patently an artificial, paraphyletic group probably comprising many taxa. Consequently, the taxonomy of haplosporidians needs a thorough revision.
\end{abstract}

KEY WORDS: Haplosporidia · Ultrastructure · Phylogeny · Urosporidium · Haplosporidium Minchinia $\cdot$ Bonamia

Resale or republication not permitted without written consent of the publisher

\section{INTRODUCTION}

The Phylum Haplosporidia is in the Kingdom Protista, super-group Rhizaria; this super-group also includes the Phyla Cercozoa, Foraminifera and Radiolaria, and Gromia spp. (Adl et al. 2005). It comprises 8 named species of Urosporidium, 23 named species of Haplosporidium, 4 named species of Bonamia, and 5 named species of Minchinia, as well as an un-named
Urosporidium sp. (Carballal et al. 2005), 3 un-named species of Haplosporidium, 1 un-named species of Minchinia, and 11 undesignated species (Burreson \& Ford 2004, Bearham et al. 2008a,b).

Bonamia has also been reported from Ostrea chilensis in Chile (Campalans et al. 2000), O. puelchana in Argentina (Kroeck \& Montes 2005), and Crassostrea ariakensis in the eastern USA (Burreson et al. 2004). Studies indicate that a spot prawn parasite (SPP) in 
Pandalus spp. (Reece et al. 2000, Bower \& Meyer 2002), and another protistan from crabs (Carcinus maenas) (Stentiford et al. 2004), are also haplosporidians. A molecular study (Reece \& Stokes 2003) places the multi-nucleate stage of a haplosporidian of $\mathrm{New}$ Zealand abalone (Haliotis iris) parasite (NZAP) (Hine et al. 2002), as phylogenetically basal to Urosporidium spp., Haplosporidium spp., Bonamia spp., and Minchinia spp.

This study is based on papers published on the ultrastructure of haplosporidians, and some unpublished observations by P. M. Hine. It does not deal with the ultrastructure of spore ornamentation, as this has recently been thoroughly reviewed by Burreson \& Reece (2006), and in subsequent studies (Bearham et al. 2008a,b). It was undertaken to compare inter-relationships based on ultrastructure with those based on molecular data, to identify features that may be important in haplosporidian taxonomy, and to consider parasite taxonomy in relation to host taxonomy. Initially, it was intended to carry out a cladistic analysis of ultrastructure, but the unevenness in the data available for each species - particularly from the studies solely of the spore stage, or asporous Bonamia spp. - did not permit such an analysis. This study highlights the need for revision of the taxonomy of haplosporidians.

\section{METHODS}

Initially, 53 ultrastructural features of haplosporidians and their effects on host cells were identified (Table 1). The features in each species were determined (Table 2) by examination of published electron micrographs. Only 2 of the 53 features have been recorded from Haplosporidium pickfordi, but 24 features have been reported from $H$. armoricanum, and many features from other ostreid Haplosporidium spp. and Bonamia spp. When the number of similarities between species was calculated, most similarities were reported for the parasites of ostreid oysters
Table 1. Ultrastructural features of haplosporidians identified

\begin{tabular}{|c|c|}
\hline $\begin{array}{l}\text { Feature } \\
\text { no. }\end{array}$ & Feature \\
\hline \multicolumn{2}{|c|}{ Uni- and bi-nucleate stages } \\
\hline 1 & Few uni- and bi-nucleate stages \\
\hline 2 & Parallel arrays of sER in uni-nucleate stages \\
\hline 3 & $\begin{array}{l}\text { Smooth endoplasmic reticulum (sER), small vesicles, cisternae or } \\
\text { microtubules between nuclei in diplokarya }\end{array}$ \\
\hline $4^{\mathrm{a}}$ & Nuclear membrane-bound Golgi (NM-BG) \\
\hline $5^{\mathrm{a}}$ & Anastomosing endoplasmic reticulum (aER) \\
\hline $6^{\mathrm{a}}$ & Vesicles budding from the outer nuclear membrane \\
\hline $7^{\mathrm{a}}$ & Indentations of the nuclear surface near NM-BG (INS) \\
\hline $8^{\mathrm{a}}$ & Possession of a cytoplasmic reticulated structure (RS). \\
\hline \multicolumn{2}{|c|}{ Plasmodia } \\
\hline $9^{\mathrm{b}}$ & Nuclear division by fission \\
\hline 10 & Amoeboid plasmodia \\
\hline 11 & Lipid droplets present \\
\hline 12 & Sparse sER and/or aER \\
\hline 13 & Cytoplasmic aggregates of dense matter \\
\hline 14 & Release of haplosporosomes from plasmodia \\
\hline 15 & Large parallel arrays of sER \\
\hline $16^{\mathrm{b}}$ & Mitochondria grouped closely around nuclei \\
\hline 17 & sER/mitochondrial complexes \\
\hline 18 & Polycomplex-like structures in the nuclei. \\
\hline \multicolumn{2}{|r|}{ Sporogony } \\
\hline 19 & $\begin{array}{l}\text { Membranes delimiting sporoblasts develop in association with } \\
\text { Golgi }\end{array}$ \\
\hline 20 & Damage to surrounding tissues at sporulation \\
\hline 21 & Formation of a syncytium \\
\hline 22 & $\begin{array}{l}\text { Floccular, filamentous or granular matter in vacuoles in the } \\
\text { episporoplasm }\end{array}$ \\
\hline 23 & Lucent vesicles in the episporoplasm \\
\hline 24 & Lipid droplets in the episporoplasm \\
\hline 25 & Microtubules in the episporoplasm. \\
\hline \multicolumn{2}{|l|}{ Spores } \\
\hline 26 & Microfilaments on the spore operculum \\
\hline 27 & Golgi cisternae throughout the sporoplasm \\
\hline 28 & $\begin{array}{l}\text { Golgi occurring as flat cisternae parallel to the sporoplasm plasma } \\
\text { membrane }\end{array}$ \\
\hline 29 & $\begin{array}{l}\text { Formative bodies (FBs) from the spherulosome (herein spherule) } \\
\text { develop into haplosporosomes }\end{array}$ \\
\hline 30 & FBs from the spherule do not develop into haplosporosomes \\
\hline 31 & Haplosporosomes develop directly from the spherule \\
\hline 32 & Sporoplasm vacuolated \\
\hline 33 & Microtubules beneath sporoplasm plasma membrane \\
\hline 34 & $\begin{array}{l}\text { Microfibrillar network perpendicular to the sporoplasm plasma } \\
\text { membrane }\end{array}$ \\
\hline 35 & Dense or lipid-like inclusions released from the sporoplasm \\
\hline 36 & Haplosporosomes released from the sporoplasm \\
\hline 37 & Exsporulation in the host \\
\hline 38 & Striated FBs in the sporoplasm \\
\hline 39 & $\begin{array}{l}\text { Cores develop in spherule-derived FBs which gain an outer } \\
\text { membrane by budding, to become haplosporosomes }\end{array}$ \\
\hline 40 & Dense aggregates in the sporoplasm \\
\hline 41 & Lipid-like or membrane-bound dense vesicles (L-LDV) \\
\hline 42 & Fibrous/filamentous spore coat \\
\hline 43 & Vertical striations in the spore wall \\
\hline 44 & Extrasporal microtubules \\
\hline 45 & Spherule formed when spore wall begins to develop \\
\hline 46 & Sporoplasm plasma membrane tight against the spore wall \\
\hline 47 & Bundles of microfibrils \\
\hline 48 & Acorn-like capped spores \\
\hline 49 & Spores with filamentous wrappings \\
\hline 50 & Spores with tails that are lost with the episporoplasm \\
\hline 51 & Spores with amorphous ribbons terminating in a 4-pronged cap \\
\hline 52 & $\begin{array}{l}\text { Internal membrane in the haplosporosome in the shape of an } \\
\text { axe-head }\end{array}$ \\
\hline 53 & NM-BG in sporoplasm \\
\hline
\end{tabular}


Table 2. Features present in each haplosporidian species. NZAP: New Zealand abalone parasite

\begin{tabular}{|ll|}
\hline Species & Features \\
\hline NZAP & $4,5,6,7,10,11,13,14,15,16,17$, \\
Urosporidium cannoni & $11,21,23,25,28,31,42,48$ \\
U. crescens & $3,4,6,10,11,12,14,20,21,25$, \\
U. spisuli & $27,31,36,37,48$ \\
U. jiroveci & $4,6,27,31,47,48$ \\
Haplosporidium & $21,23,31,48$ \\
$\quad$ louisiana & $3,4,5,6,11,12,16,18,21,22,32$, \\
H. nelsoni & $37,38,39,43,49$ \\
& $3,4,5,6,9,10,11,13,14,20,30$, \\
H. costale & $37,43,44,46,49$ \\
H. armoricanum & $1,3,4,5,6,7,11,12,13,16,20$, \\
& $29,35,40,42,49,52$ \\
H. comatulae & $1,2,4,5,7,9,11,12,13,16,17$, \\
H. ascidiarum & $19,22,23,24,29,33,35,41,46$, \\
H. lusitanicum & $47,49,52,53$ \\
& $11,16,18,21,22,23,24,30,32,49$ \\
H. pickfordi & $11,16,19,22,29,32,42$ \\
H. montforti & $11,19,20,24,26,30,35,36,37$, \\
Bonamia perspora & $41,45,46,49$ \\
& $35,41,49$ \\
B. exitiosa & $21,41,49$ \\
B. ostreae & $1,2,4,5,8,10,11,15,16,19,24$, \\
Minchinia dentali & $29,36,39,41,45,47,51,53$ \\
M. tapetis & $2,4,5,6,7,8,11,12,13,15,16$ \\
M. teredinis & 4,5 \\
M. chitonis & $10,20,25,26,29,36,37,50$ \\
M. occulta & $20,26,33,34,37,39,50$ \\
& $1,25,34,38,39,50$ \\
\hline & $7,10,11,12,24,25,29,37,40,42$, \\
& $44,46,47$ \\
\hline
\end{tabular}

(Table 3), because there is a correlation between the number of features recorded and the number of similarities to other species (Fig. 1). There is also disparity in the stages reported. Only the late sporulation stages and spores of Urosporidium spp., H. edule, H. parisi, Minchinia teredinis and $M$. chitonis are reported, while the NZAP, and asporous Bonamia spp. are only known from vegetative stages.

Therefore, recognising the limitations of quantative comparison of features, a more qualitative approach was taken to identify patterns within genera and groups. Other possible sources of bias were

- Different authors may interpret what they see in different ways, or they may concentrate on some features more than others. This is here called the 'observer effect'. The studies of Perkins (1968, 1969, $1971,1975,1979)$ contain much information, which may result in more linkages between the species he described than between species described by other workers (Tables 2 \& 3). For example, only Perkins (1968, 1969, 1971, 1975) has reported smooth endoplasmic reticulum (sER), small vesicles, cisternae or microtubules between nuclei in diplokarya.

- The presence of a feature can be relied upon, but the absence of a feature cannot, as it might just have not

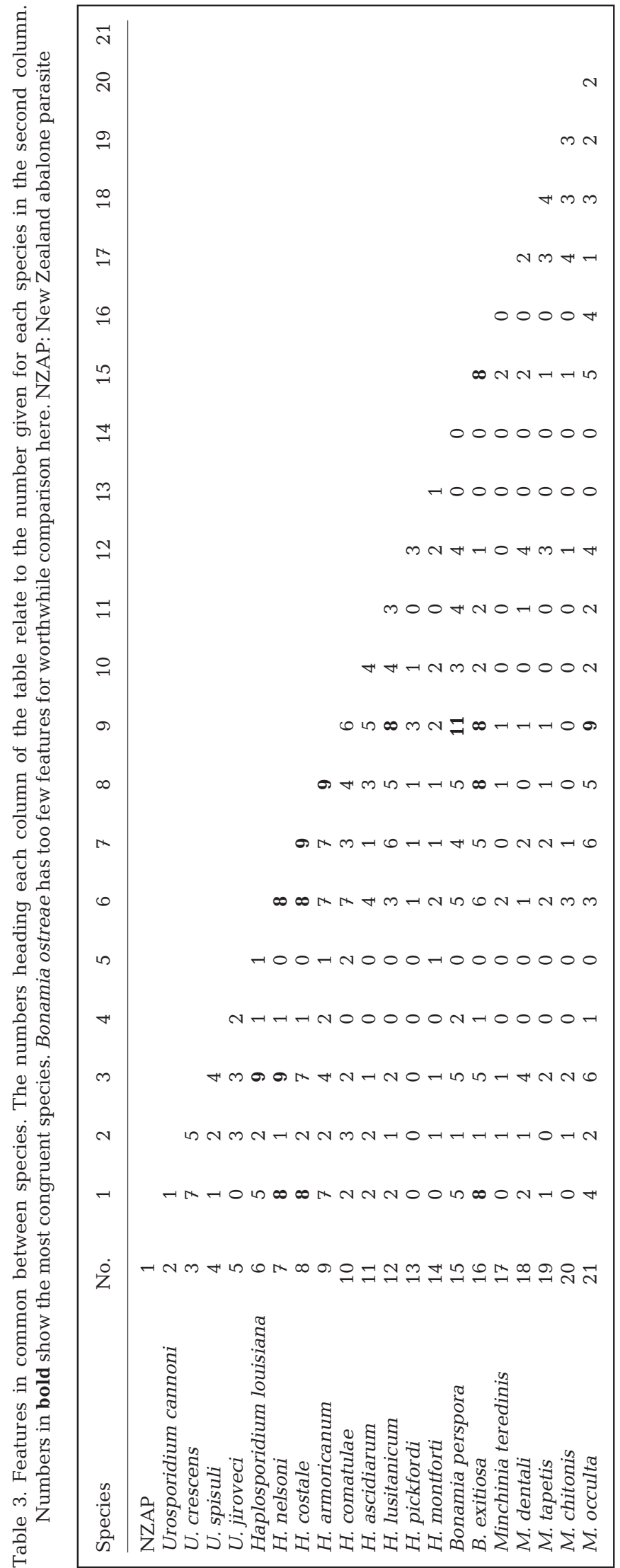




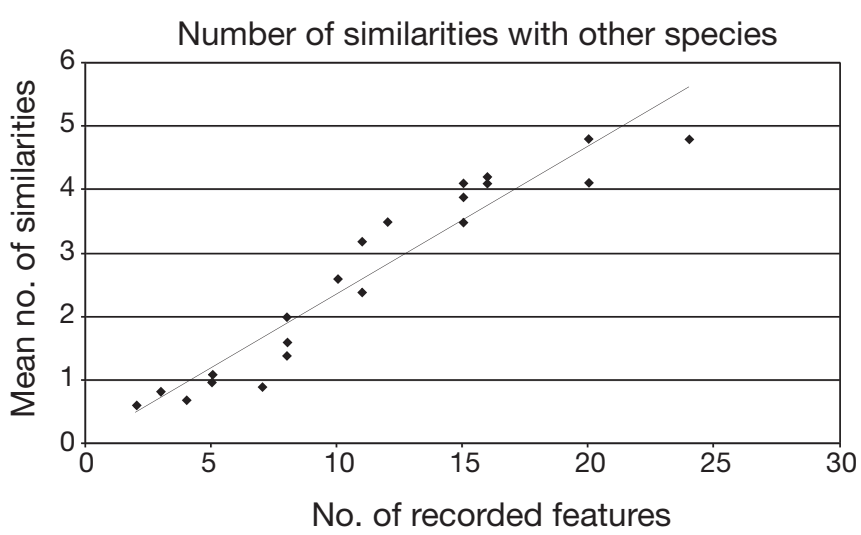

Fig. 1. Correlation of the mean number of recorded features and the mean number of similarities between species. The fewer the features reported, the less likelihood there will be of similarities, unless the few features reported are the same.

Except for spore ornamentation, this is seldom the case

been seen, or the material examined was unsuitable. For example, development of the spore walls at nodes has been reported for all Haplosporidium spp. and Minchinia spp., except $H$. lusitanicum, but spore wall development is almost certainly nodal in the latter species.

- Not all of the 53 features listed in Table 1 are likely to be of equal importance in identifying similarities and differences between species.

- The results vary depending on how much emphasis is put on a group of features, such as the many ultrastructural features in tails of Urosporidium spp.

- Assumption that a feature was permanently present, and not transient during a specific process (e.g. occurrence of microfilaments on the operculum during sporulation).

Not all described species are included in Tables 2 to 5 because descriptions of some species lack sufficient relevant information to be of use. Haplosporidium cadomensis Marchand \& Sprague, 1979, is considered a synonym of $H$. louisiana Sprague, 1963, and the haplosporidian of Crassostrea gigas described by Comps \& Pichot (1991), is regarded as $H$. costale-like. The multi-nucleate plasmodia of a haplosporidian of Ostrea edulis from St Philibert, Brittany, France (Bréhelin et al. 1982, Vivarès et al. 1982, Bonami et al. 1985) are regarded as those of $H$. armoricanum, which also occurs in $O$. edulis at that site (van Banning 1977, Hine et al. 2007). The Haplosporidium sp. reported from rock oysters Saccostrea cuccullata by Hine \& Thorne (2002) was reclassified as Minchinia sp. on the basis of a molecular study (Bearham et al. 2007), and described as M. occulta Bearham et al. (2008b).

\section{RESULTS AND DISCUSSION}

\section{Analysis of features and comparison with molecular phylogenies}

Many features were only seen in 1 or 2 species, or were nearly ubiquitous. Little can be concluded from their occurrence and therefore they are not considered below.

\section{Occurrence of aER, NM-BG, INS and cytoplasmic} aggregates of dense matter

These 4 features may be constituents of the transGolgi network (Figs. 3 to 7 in Hine et al. 2002), and therefore the occurrence of one of these features may indicate the presence of the others. As well as in the NZAP, anastomosing endoplasmic reticulum (aER) occurs in 1 crustacean (Haplosporidium louisiana), and 6 haplosporidians infecting ostreid oysters (Table 4). Nuclear membrane-bound Golgi (NM-BG) occur in the NZAP, Urosporidium spisuli, H. louisiana, haplosporidians of ostreid oysters, and a crab haplosporidian

Table 4. Literature source electronmicrographs revealing the presence of 4 ultrastructural features - anastomosing endoplasmic reticulum (aER), nuclear membrane-bound Golgi (NM-BG), indentations of the nuclear surface (INS), and cytoplasmic aggregates of dense matter (cyto) - in haplosporidian species. NZAP: New Zealand abalone parasite

\begin{tabular}{|c|c|c|c|c|c|}
\hline \multirow[t]{2}{*}{$\begin{array}{l}\text { Haplosporidian } \\
\text { species }\end{array}$} & \multicolumn{4}{|c|}{$\begin{array}{c}\text { Source figure(s) } \\
\text { revealing feature }\end{array}$} & \multirow[t]{2}{*}{ Source } \\
\hline & aER & NM-BG & INS & Cyto & \\
\hline NZAP & $3-7$ & $3-7$ & 2 & 12 & Hine et al. (2002) \\
\hline Haplosporidium louisiana & 3 & & & & Perkins (1975) \\
\hline H. nelsoni & & $17-19$ & & & Perkins (1979) \\
\hline H. costale & 1 & & 9 & $6-9$ & Perkins (1969) \\
\hline H. armoricanum & & & 4 & 4 & Cahour et al. (1980) \\
\hline H. armoricanum & & 2 & & & Bonami et al. (1985) \\
\hline H. armoricanum & & 7,8 & 2,7 & 2 & Hine et al. (2007) \\
\hline Bonamia ostreae & 2 & 2 & & & Hervio et al. (1991) \\
\hline B. perspora & 30 & 29 & & & Carnegie et al. (2006) \\
\hline B. exitiosa & 2,3 & 14 & & 13 & Hine \& Wesney (1992) \\
\hline B. exitiosa & 6 & & & & Hine \& Wesney (1994) \\
\hline B. exitiosa & 3 & & & & Hine et al. (2001) \\
\hline B. exitiosa & & 3 & & & Hine (1991) \\
\hline B. exitiosa & & $3,10,12$ & & 4 & Hine (1992) \\
\hline Urosporidium spisuli & & 17 & & & Perkins (1979) \\
\hline Minchinia occulta & & & 10 & 10 & Hine \& Thorne (2002) \\
\hline Carcinus maenas parasite & & 18 & & & Stentiford et al. (2004) \\
\hline
\end{tabular}


(Table 4). NM-BG occur in the spores of Bonamia perspora (Carnegie et al. 2006) and H. armoricanum (Hine et al. 2007). NM-BG were not reported from Haplosporidium costale by Perkins (1969), but they were not originally reported in Haplosporidium nelsoni either (Perkins 1968), only later (Figs. 17 to 19 in Perkins 1979), and may not have been observed in Perkins (1969). Similarly, NM-BG were also not reported from Minchinia occulta (Hine \& Thorne 2002, Bearham et al. 2008b), but vegetative stages were rarely observed. Indentations in the nuclear surface (INS) have been reported in the NZAP and 3 ostreid haplosporidians (Table 4). INS have not been reported from H. nelsoni (Perkins 1968), B. perspora (Carnegie et al. 2006), or B. ostreae (Pichot et al. 1980). In the last case, this may be because INS are usually observed in plasmodia, and $B$. ostreae very rarely develops into plasmodia.

Cytoplasmic aggregates of dense matter, sometimes associated with the aER/NM-BG/INS complex, occur in the NZAP, Haplosporidium costale, H. armoricanum, Minchinia occulta, M. chitonis, and Bonamia exitiosa (Table 4). Perinuclear dense matter is rarely seen in $H$. nelsoni (P. M. Hine unpubl. obs.), but large cytoplasmic aggregates in which haplosporosomes develop - and from which they bud, acquiring the outer haplosporosome membrane-are a prominent feature of $H$. nelsoni plasmodia (Perkins 1968, 1979). They have not been reported from other Haplosporidium spp. Vesicles bud from the nuclear membrane into the aER/ NMBG/INS complex in the NZAP (Fig. 7 in Hine et al. 2002), Urosporidium spisuli (Fig. 17 in Perkins 1979), H. louisiana (Perkins 1979), H. nelsoni (Fig. 18 in Perkins 1979), H. costale (Fig. 6 inset in Perkins 1969) and B. exitiosa (Fig. 16 in Hine \& Wesney 1994).

Therefore, there appear to be many ultrastructural linkages between the NZAP, ostreid haplosporidians (Haplosporidium nelsoni, $H$. costale, H. armoricanum, Bonamia spp., Minchinia occulta), H. louisiana, and some Urosporidium spp., and Minchinia spp. This may reflect the number of studies carried out, and, as many of these studies have been by Perkins (1968, 1969, 1975, 1979) and Hine (Hine 1991, 1992, Hine \& Thorne 2002, Hine \& Wesney 1992, 1994, Hine et al. 2001, 2002, 2007, Stentiford et al. 2004, Carnegie et al. 2006), it may be due to the observer effect.
Haplosporogenesis

Patterns in haplosporogenesis may be taxonomically important. The direct development of haplosporosomes from the spherule links Urosporidium spp., and distinguishes the genus from other genera. Acquisition of an external membrane by cores budding from formative bodies (FBs) occurs in Haplosporidium louisiana, and Bonamia perspora, and is common in Minchinia spp. (Table 5). The FBs possess striated cores in H. louisiana (Perkins 1975, Marchand \& Sprague 1979), M. chitonis (see Ball 1980) and M. teredinis (Hillman et al. 1990). Similarly, haplosporosomes develop from FBs in $M$. occulta, but they are not striated (Hine \& Thorne 2002). A Minchinia sp. of Mytilus galloprovincialis also has electron dense vesicles, haplosporosomes, and large (300 to $500 \mathrm{~nm}$ ) osmiophilic bodies in the spores, similar to those illustrated in M. teredinis (Fig. 3 in McGovern \& Burreson 1990), but whether the haplosporosomes formed in, and budded from, the electron dense vesicles was not reported (Comps \& Tigé 1997). Budding of cores from FBs to acquire an outer membrane and thus form haplosporosomes also occurs in H. nelsoni, but in the plasmodia,

Table 5. Haplosporogenesis. Literature sources (with their respective figures) revealing the occurrence of cores budding from formative bodies, and haplosporosome and lipid-like vesicle release in haplosporidian species. NZAP: New Zealand abalone parasite

\begin{tabular}{|lcl|}
\hline \multicolumn{2}{|c|}{ Haplosporidian species } & \multicolumn{2}{l}{ Fig. no. } & Source \\
\hline Cores budding from formative bodies & \\
Haplosporidium louisiana & 28,29 & Perkins (1975) \\
H. louisiana & 14,15 & Marchand \& Sprague (1979) \\
Bonamia perspora & 37 & Carnegie et al. (2006) \\
Minchinia chitonis & $1 \mathrm{C}, 1 \mathrm{D}$ & Ball (1980) \\
M. tapetis & 13 & Azevedo \& Corral (1989) \\
M. teredinis & 6,7 & Hillman et al. (1990) \\
Haplosporosomes released from plasmodia or sporonts \\
NZAP & 17 & Hine et al. (2002) \\
Urosporidium crescens & 5 & Perkins (1971) \\
H. nelsoni & 15 & Perkins (1979) \\
B. perspora & 39 & Carnegie et al. (2006) \\
Release of lipid-like or membrane-bound dense vesicles \\
H. armoricanum & 9 & Hine et al. (2007) \\
H. costale & 9 & Rosenfield et al. (1969) \\
H. costale-like & $2 \mathrm{~b}$ & Comps \& Pichot (1991) \\
H. lusitanicum & 3 & Azevedo \& Corral (1985) \\
H. lusitanicum & 2 & Azevedo et al. (1985) \\
H. montforti & 11 & Azevedo et al. (2006) \\
H. pickfordi & 12 & Burreson (2001) \\
B. perspora & 39 & Carnegie et al. (2006) \\
Axe-head shaped haplosporosomes & \\
H. costale & 21 & Perkins (1969) \\
H. costale & 6 & Rosenfield et al. (1969) \\
H. costale-like & 2 a & Comps \& Pichot (1991) \\
H. armoricanum & 6 & Cahour et al. (1980) \\
H. armoricanum & 11 & Hine et al. (2007) \\
& & \\
\end{tabular}


not the spores (Perkins 1968, 1979). The spore haplosporosomes of $H$. costale, a $H$. costale-like parasite from Crassostrea gigas (see Comps \& Pichot 1991), and H. armoricanum, are axe-head shaped and ultrastructurally difficult to tell apart (Table 5).

Haplosporosomes are released from plasmodia in the NZAP, Haplosporidium nelsoni, and Bonamia perspora, and from sporonts and the sporoplasm in Urosporidium crescens. Lipid-like or membrane-bound dense vesicles (L-LDV), which may be released, occur at the periphery of the sporoplasm of gastropod haplosporidian species (H. lusitanicum, H. pickfordi, H. montforti); however, similar L-LDVs occur in, and may be released from, $H$. costale, an $H$. costale-like parasite, H. armoricanum, and B. perspora (Table 5). The genesis and function of L-LDVs, and their relationship to haplosporosomes, is unclear. Cytochemical studies on $H$. lusitanicum spores have shown that L-LDVs in the peripheral endosporoplasm, and dense bodies (DBs) in the episporoplasm, stain strongly for glycoproteins and for lipids (Azevedo \& Corral 1985, 1989). Haplosporosomes in the same spores were positive for lipids in their internal membrane, and positive for glycoproteins in the external membrane and matrix. However, although L-LDVs in the endosporoplasm and DBs in the episporoplasm resembled each other cytochemically, haplosporosomes only occurred in the endosporoplasm, making it unlikely that, either L-LDVs and DBs are the same, or that haplosporosomes develop from L-LDVs. The spherical bodies around the sporoplasm of Minchinia dentali (Fig. 44 in Desportes \& Nashed 1983) appear to be different, having a composition similar to that of the cytoplasm.

Relationships based on ultrastructure

Taking these shared ultrastructural features and the numbers of similarities between species in Table 2 into account, a tree diagram was constructed to illustrate the most likely inter-relationships (Fig. 2). Species other than the 3 Haplosporidium spp. from gastropods, and Minchinia spp. have aER/NM-BG/INS complexes, except $M$. occulta which also has INS. M. occulta occurs predominantly as uni-nucleate and bi-nucleate Bonamia-like forms, leading Bearham et al. (2008b) to conclude that the single uni-nucleate stage may become more dominant in the life cycles of Haplosporidia in species more closely related to Bonamia. The occurrence of INS, predominance of uni-nucleate stages and occurrence in an ostreid host suggests that M. occulta is more closely related to Bonamia spp., than are other Minchinia spp. The NZAP (Fig. 12 in Hine et al. 2002), B. perspora (Fig. 30 in Carnegie et al. 2006) and B. exitiosa (Fig. 6 in Hine \& Wesney 1994) possess a cytoplasmic reticulated structure, which may also be part of the aER/NM-BG/INS complex.

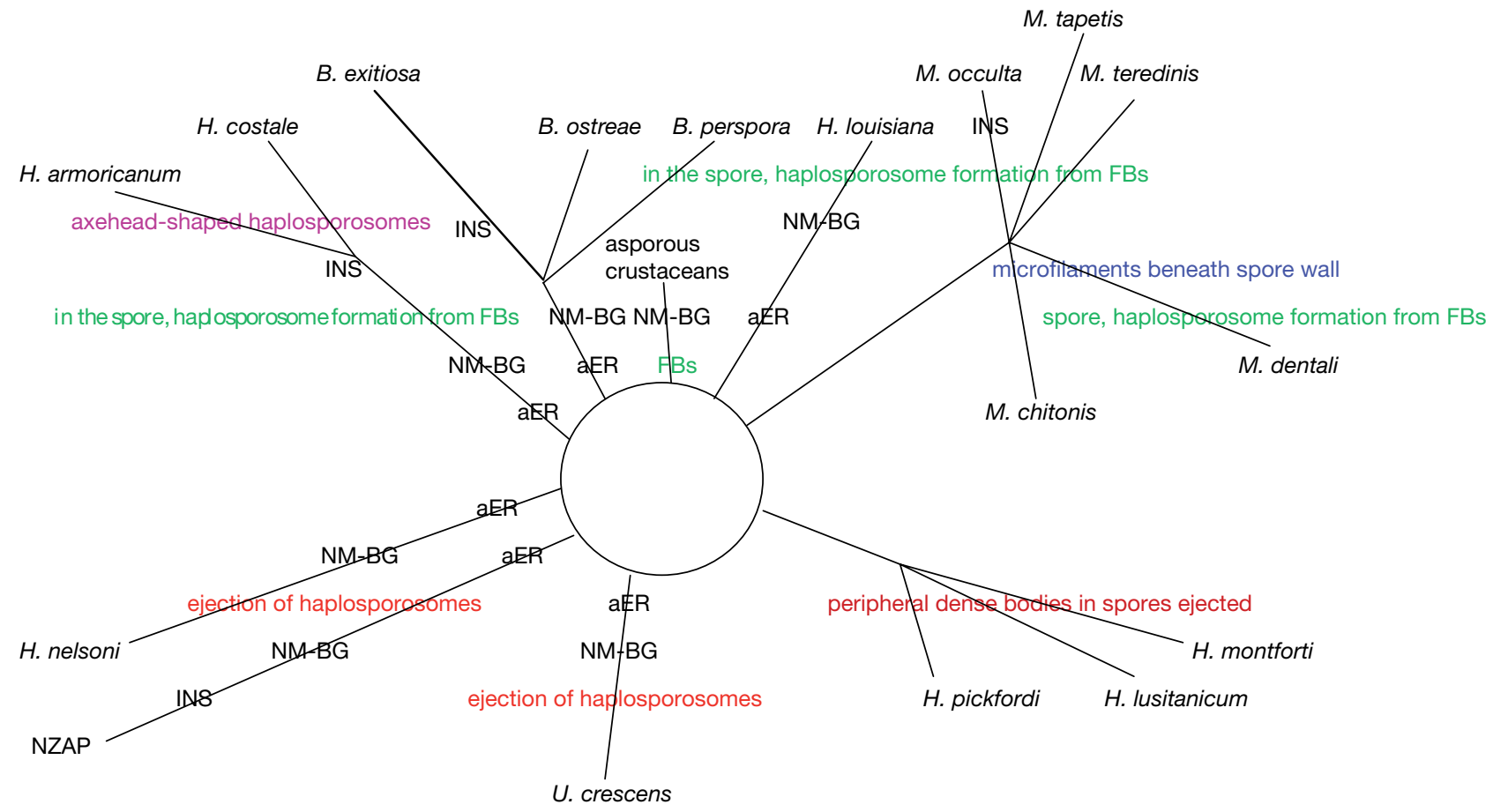

Fig. 2. The apparent haplosporidian inter-relationships, based on ultrastructural data. The features occurring in each species are given by the abbreviations crossing the lines leading to each species. Line length does not indicate relatedness. NM-BG: nuclear membrane-bound Golgi; INS: indentations in the nuclear surface; aER: anastomosing endoplasmic reticulum; FBs: formative bodies. See Table 2 for full species names 
Bonamia perspora (Carnegie et al. 2006), Haplosporidium louisiana (Perkins 1975, Marchand \& Sprague 1979), Minchinia spp., H. armoricanum and $H$. costale, undergo haplosporogenesis in the spore in 2 stages: production of vesicles by the spherule and their subsequent development into haplosporosomes. In particular, B. perspora, H. louisiana, M. tapetis and M. teredinis, form haplosporosomes by cores budding from the vesicles to acquire an outer haplosporosome membrane. H. armoricanum (Fig. 9 in Hine et al. 2007) and B. perspora (Carnegie et al. 2006) have NM-BG in the endosporoplasm. H. armoricanum (see Bachère \& Grizel 1983), B. perspora (Carnegie et al. 2006), and $B$. exitiosa (Fig. 4 in Hine \& Wesney 1994) have parallel arrays of sER in uni-nucleate stages.

Asporous haplosporidians from some crustaceans, including crabs (Newman et al. 1976, Stentiford et al. 2004), and prawns (Dyková et al. 1988), resemble Bonamia ostreae (see Brehélin et al. 1982), B. exitiosa (see Hine 1991), and possibly B. roughleyi (Cochennec-Laureau et al. 2003), in the development of uninucleate stages into multi-nucleate plasmodia, which may then divide to form more uni-nucleate stages. This may be due to reduction in the life cycles from sporeforming ancestors (Stentiford et al. 2004), such as Haplosporidium louisiana and B. perspora. A haplosporidian (Reece et al. 2000) from spot prawns Pandalus platyceros, with many stages that are not observed in other haplosporidians (Bower \& Meyer 2002), has cytoplasmic bodies in the uni-nucleate stage that may be FBs preceding haplosporosomes.

The placing of species in Fig. 2 does not show several linkages because it is a 2-dimensional representation of a 3-dimensional structure. L-LDVs tight against the endosporoplasm membrane, or between the endosporoplasm and spore wall, not only occur in gastropod Haplosporidium spp. (H. lusitanicum, H. pickfordi and H. montforti), but also in $H$. costale (Rosenfield et al. 1969), H. armoricanum (Hine et al. 2007) and Bonamia perspora (Carnegie et al. 2006). H. nelsoni (Fig. 18 in Perkins 1968), Minchinia occulta (Fig. 17 in Hine \& Thorne 2002), and $H$. ascidiarum (see Ormières \& de Puytorac 1968) have extrasporal microtubules. H. nelsoni (Fig. 10 in Perkins 1968) and H. armoricanum (Fig. 3 in Hine et al. 2007) may undergo nuclear division by fission. H. nelsoni (Fig. 3 in Rosenfield et al. 1969) shares vertical striations in the spore wall with H. louisiana (Fig. 17 in Marchand \& Sprague 1979; Fig. 8 in Perkins \& van Banning 1981). H. lusitanicum (Fig. 5 in Azevedo 1984) is linked to M. dentali (Fig. 40 in Desportes \& Nashed 1983) and M. tapetis (Fig. 5 in Azevedo \& Corral 1989), by possession of opercular microfilaments. These may be transient and associated with exsporulation (Azevedo \& Corral 1989), but they have not been observed on the operculae of Haplo- sporidium spp. or M. occulta (Hine \& Thorne 2002, Bearham et al. 2008b).

\section{Comparison with molecular phylogenies}

Fig. 2 resembles molecular phylogeny, in terms of the relationships of the NZAP to ostreid haplosporidians and to Urosporidium spp. (Reece et al. 2004, Azevedo et al. 2006, Carnegie et al. 2006). However, in Fig. 2, Haplosporidium louisiana is not basal to U. crescens, and ostreid haplosporidians, Bonamia spp. and Minchinia spp. (Carnegie \& Cochennec-Laureau 2004, Reece et al. 2004, Azevedo et al. 2006, Carnegie et al. 2006), but it is placed between Bonamia spp. and Minchinia spp. The relationship with the latter and $H$. costale has recently been supported in phylogenies based on actin gene sequences (López-Flores et al. 2007), and on a prawn haplosporidian (Nunan et al. 2007). Future studies may confirm the placing of crustacean haplosporidians close to or between Bonamia spp. and Minchinia spp. The possible close relationship between the gastropod Haplosporidium spp. and $H$. costale, in possession of L-LDVs tight against the endosporoplasm plasma membrane, reflects the phylogenies of Reece et al. (2004), Azevedo et al. (2006), and Carnegie et al. (2006). Peripheral dense bodies and the axehead shape of haplosporosomes in spores suggests that $H$. costale and $H$. armoricanum are closely related, as in the phylogeny of Carnegie \& Cochennec-Laureau (2004).

Haplosporidian molecular phylogenies and spore ornamentation (Burreson \& Reece 2006) indicate that while Urosporidium spp., Minchinia spp., and Bonamia spp. are monophyletic, Haplosporidium spp. are paraphyletic (Burreson \& Ford 2004, Burreson \& Reece 2006). This is supported by ultrastructure. Haplosporidium species are each distinguished from others in the genus as follows: $H$. nelsoni by haplosporosomeformative areas in the plasmodial cytoplasm (Perkins 1968); $H$. montforti by filaments coming off the posterior of the spore, and from underneath the operculum; $H$. hinei by filaments arising from 2 posterior knobs that subsequently pass under the operculum (Bearham et al. 2008a); H. edule by spore ornamentation (Azevedo et al. 2003); H. comatulae by spore haplosporogenesis resembling $M$. chitonis (La Haye et al. 1984); $H$. ascidiarum by electron opaque inclusion bodies in the spores (Ciancio et al. 1999); and $H$. parisi by absence of haplosporosomes and possession of 'organites' in the spore (Ormières 1980). As the type Haplosporidium sp. (H. scolopli Caullery and Mesnil, 1899) was described from a polychaete, and $H$. parisi is the only species described ultrastructurally from a polychaete, $H$. parisi may resemble $H$. scolopli. If so, none 
of the other ultrastructurally described Haplosporidium spp. belong in that genus, and-except for H. costale, H. armoricanum and the gastropod Haplosporidium spp. - none are congeneric. The spore ornamentation of $H$. hinei shows some similarities to H. parisi (see Bearham et al. 2008a). However, their sporoplasm ultrastructure is very different (Hine \& Thorne 1998), suggesting that spore ornamentation alone is not a reliable taxonomic indicator. Similarly, among Urosporidium spp., the type species (U. fuliginosum Caullery and Mesnil, 1905) is the only species isolated from a polychaete, the other species deriving from helminths and a turbellarian (Burreson \& Ford 2004). Although Minchinia spp. are considered to be monophyletic, if spore ornamentation is a taxonomic indicator, the presence of microtubules over the surface (which might give rise to a ridge on the spore) and lack of epispore cytoplasmic extensions distinguishes M. occulta from other Minchinia spp., showing that there may be considerable variation within monophyletic groups.

\section{Phylogenetic patterns in relation to the taxonomy of host species}

Urosporidium spp. infect lower invertebrates, notably trematodes, but also a nematode, turbellarians and a polychaete (Burreson \& Ford 2004). U. cannoni, which infects a turbellarian, differs from other Urosporidium spp. in several respects: it has 11 to 13 tails, rather than the usual 1 to 3 of other species, an episporal fibrillar system of a network of complex microtubule-like fibrils, vermiform projections from the cyst wall, parallel Golgi cisternae, and spherical mitochondria (Anderson et al. 1993). Although U. cannoni almost certainly belongs in another genus, another Urosporidium sp. parasitizing a turbellarian resembles U. spisuli (see Carballal et al. 2005). Haplosporidium costale, $H$. armoricanum and Bonamia spp. are parasites of ostreid oysters. H. lusitanicum, H. pickfordi and $H$. montforti are all parasites of gastropods. In Fig. 2, the positions of haplosporidians from abalone, the NZAP and H. montforti, are distant from each other. However, the NZAP infects Haliotis iris, which is phylogenetically distant from all other Haliotis spp. (Coleman \& Vacquier 2002), and probably diverged from them at the break-up of Gondwanaland. Minchinia spp. infect different classes of molluscs: M. dentali in a scaphopod, M. chitonis in a polyplacophoran, and M. teredinis, M. occulta (Bearham et al. 2008b) and Minchinia sp. (Comps \& Tigé 1997) in different families of bivalves. H. louisiana is a parasite of decapods that, unlike other known haplosporidians of crustaceans (Newman et al. 1976, Dyková et al. 1988,
Bower \& Meyer 2002, Stentiford et al. 2004, Nunan et al. 2007), forms spores. Observations on the other crustacean haplosporidians suggest that, for at least part of their life-cycles, they form large multi-nucleate plasmodia that internally divide to form uni-nucleate bodies, which separate and undergo karyokinesis to form multi-nucleate plasmodia, and the cycle is repeated.

Within the Phylum Haplosporidia, Urosporidium spp. are in the Family Urosporidiidae, and Haplosporidium spp. and Minchinia spp. are in the Family Haplosporidiidae (Perkins 2000). Bonamia spp. have not been clearly placed within this family, but the operculate spores of B. perspora (Carnegie et al. 2006) suggest that it is closer to Haplosporidium spp. and Minchinia spp. than to Urosporidium spp. Thus, the phylum comprises 2 families with 4 genera, yet both genotypic and phenotypic studies suggest considerable diversity that is not recognised in haplosporidian taxonomy, particularly within Haplosporidium spp. The conservative placing of diverse haplosporidians into just 2 families may reflect the initial lumping of the ultrastructurally very different paramyxeans into the same Phylum Ascetospora by Sprague (1979) (Burreson \& Ford 2004). The Haplosporidia and Paramyxea were subsequently separated (Desportes \& Perkins 1990), and the Phylum Haplosporidia is now recognised (Adl et al. 2005). There is an urgent need for a major taxonomic revision of the Haplosporidia based on molecular and ultrastructural studies, to clarify taxonomic relationships, in particular to provide a structure to accommodate the many diverse Haplosporidium spp.

\section{LITERATURE CITED}

Adl SM, Simpson AGB, Farmer MA, Andersen RA and others (2005) The new higher level classification of eukaryotes with emphasis on the taxonomy of protists. J Eukaryot Microbiol 52:399-451

Anderson TJ, Newman LJ, Lester RJG (1993) Light and electron microscope study of Urosporidium cannoni n. sp. haplosporidian parasite of the polyclad turbellarian Stylochus sp. J Eukaryot Microbiol 40:162-168

Azevedo C (1984) Ultrastructure of the spore of Haplosporidium lusitanicum sp. n. (Haplosporida, Haplosporidiidae), parasite of a marine mollusc. J Parasitol 70:358-371

Azevedo C, Corral L (1985) Cytochemical analysis of the haplosporosomes and vesicle-like droplets of Haplosporidium lusitanicum (Haplosporida, Haplosporidiidae), parasite of Helcion pellucidus (Prosobranchia). J Invertebr Pathol 46: 281-288

Azevedo C, Corral L (1989) Fine structural observations of the natural spore excystment of Minchinia sp. (Haplosporida). Eur J Protistol 24:168-173

Azevedo C, Corral L, Perkins FO (1985) Ultrastructural observations of spore excystment, plasmodial development and sporoblast formation in Haplosporidium lusitanicum (Haplosporida, Haplosporidiidae). Z Parasitenkd 71:715-726

- Azevedo C, Conchas RF, Montes J (2003) Description of Haplosporidium edule $\mathrm{n}$. sp. (Phylum Haplosporidia), a para- 
site of Cerastoderma edule (Mollusca, Bivalvia) with complex spore ornamentation. Eur J Protistol 39:161-167

Azevedo C, Balseiro P, Casal G, Gestal C and others (2006) Ultrastructural and molecular characterization of Haplosporidium montforti, n. sp., parasite of the European abalone Haliotis tuberculata. J Invertebr Pathol 92:23-32

Bachère E, Grizel H (1983) Mise en évidence d'Haplosporidium sp. (Haplosporida-Haplosporidiidae) parasite de l'huître plate Ostrea edulis. Rev Trav Inst Pêches Marit 46: 226-232

Ball SJ (1980) Fine structure of the spores of Minchinia chitonis (Lankester, 1885) Labbé, 1896 (Sporozoa: Haplosporida), a parasite of the chiton, Lepidochitona cinereus. Parasitology 81:169-176

Bearham D, Spiers Z, Raidal S, Jones JB, Nicholls PK (2007) Molecular characterisation of a haplosporidian parasite infecting rock oysters Saccostrea cuccullata in northern Western Australia. J Invertebr Pathol 95:33-40

Bearham D, Spiers Z, Raidal S, Jones JB, Burreson EM, Nicholls PK (2008a) Spore ornamentation of Haplosporidium hinei n. sp. (Haplosporidia) in pearl oysters Pinctada maxima (Jameson, 1901). Parasitology 135:521-527

Bearham D, Spiers Z, Raidal S, Jones JB, Nicholls PK (2008b) Spore ornamentation of Minchinia occulta n. sp. (Haplosporidia) in rock oysters Saccostrea cuccullata (Born, 1778). Parasitology 135:1271-1280

Bonami JR, Vivarès CP, Bréhelin M (1985) Étude d'une nouvelle haplosporidie parasite de l'huître plate Ostrea edulis L.: morphologie et cytologie de différents stades. Protistologica 21:161-173

Bower SM, Meyer GR (2002) Morphology and ultrastructure of a protistan pathogen in the haemolymph of shrimp (Pandalus spp.) in the northern Pacific Ocean. Can J Zool 80:1055-1068

Brehélin M, Bonami JR, Cousserans F, Vivarès CP (1982) Existence de formes plasmodiales vraies chez Bonamia ostreae parasite de l'huître plate Ostrea edulis. C R Acad Sci Paris 295:45-48

- Burreson EM (2001) Spore ornamentation of Haplosporidium pickfordi Barrow, 1961 (Haplosporidia), a parasite of freshwater snails in Michigan, USA. J Eukaryot Microbiol 48:622-626

Burreson EM, Ford SE (2004) A review of recent information on the Haplosporidia, with special reference to Haplosporidium nelsoni (MSX disease). Aquat Living Resour $17: 499-517$

Burreson EM, Reece KS (2006) Spore ornamentation of Haplosporidium nelsoni and Haplosporidium costale (Haplosporidia), and incongruence of molecular phylogeny and spore ornamentation in the Haplosporidia. J Parasitol 92:1295-1301

Burreson EM, Stokes NA, Carnegie RB, Bishop MJ (2004) Bonamia sp. (Haplosporidia) found in non-native oysters Crassostrea ariakensis in Bogue Sound, North Carolina. $\mathrm{J}$ Aquat Anim Health 16:1-9

Cahour A, Poder M, Balouet G (1980) Présence de Minchinia armoricana (Haplosporea, Haplosporida) chez Ostrea edulis d'origine francaise. C R Soc Biol 174:359-368

Campalans M, Rojas P, Gonzalez M (2000) Haemocytic parasitosis in the farmed oyster Tiostrea chilensis. Bull Eur Assoc Fish Pathol 20:31-33

> Carballal MJ, Diaz S, Villalba A (2005) Urosporidium sp. hyperparasite of the turbellarian Paravortex cardii in the cockle Cerastoderma edule. J Invertebr Pathol 90:104-107

Carnegie RB, Cochennec-Laureau N (2004) Microcell parasites of oysters: recent insights and future trends. Aquat Living Resour 17:519-528
Carnegie RB, Burreson EM, Hine PM, Stokes NA, Audemard C, Bishop MJ, Peterson PH (2006) Bonamia perspora n. sp. (Haplosporidia), a parasite of the oyster Ostreola equestris, is the first Bonamia species known to produce spores. J Eukaryot Microbiol 53:232-245

Caullery M, Mesnil F (1899) Sur le genre Aplosporidium (nov) et l'ordre nouveau des Aplosporidies. C R Soc Biol 51: 789-791

Caullery M, Mesnil F (1905) Sur quelques nouvelles haplosporodies d'Annelide. C R Soc Biol 58:580-583

Ciancio A, Srippa S, Izzo C (1999) Ultrastructure of vegetative and sporulation stages of Haplosporidium ascidiarium from the ascidian Ciona intestinalis L. Eur J Protistol 35: 175-182

Cochennec-Laureau N, Reece KS, Berthe FCJ, Hine PM (2003) Mikrocytos roughleyi taxonomic affiliation leads to the genus Bonamia (Haplosporidia). Dis Aquat Org 54: 209-217

Coleman AW, Vacquier VD (2002) Exploring the phyogenetic utility of ITS sequences for animals: a test case for abalone (Haliotis). J Mol Evol 54:246-257

Comps M, Pichot Y (1991) Fine spore structure of a haplosporidan parasitizing Crassostrea gigas: taxonomic implications. Dis Aquat Org 11:73-77

Comps M, Tigé G (1997) Fine structure of Minchinia sp., a haplosporidan infecting the mussel Mytilus galloprovincialis. Syst Parasitol 38:45-50

Desportes I, Nashed NN (1983) Ultrastructure of sporulation in Minchinia dentali (Arvy), an haplosporean parasite of Dentalium entale (Scaphopoda, Mollusca); taxonomic implications. Protistologica 19:435-460

Desportes I, Perkins FO (1990) Phylum Paramyxea. In: Margulis L, Corliss JO, Melkonian M, Chapman DJ (eds) Handbook of Protoctista. Jones and Bartlett Publishing, Boston, MA, p 30-35

Dyková I, Lom J, Fajer E (1988) A new haplosporean infecting the hepatopancreas in the penaeid shrimp, Penaeus vannamei. J Fish Dis 11:15-22

> Hervio D, Chagot D, Godin P, Grizel H, Mialhe E (1991) Localization and characterization of acid phosphatase activity in Bonamia ostreae (Ascetospora), an intrahemocytic protozoan parasite of the flat oyster Ostrea edulis (Bivalvia). Dis Aquat Org 12:67-70

Hillman RE, Ford SE, Haskin HH (1990) Minchinia teredinis n. sp. (Balanosporida, Haplosporidiidae), a parasite of teredinid shipworms. J Protozool 37:364-368

- Hine PM (1991) Ultrastructural observations on the annual infection pattern of Bonamia sp. in flat oysters Tiostrea chilensis. Dis Aquat Org 11:163-171

Hine PM (1992) Ultrastructural and enzyme cytochemical observations on Bonamia sp. in oysters (Tiostrea chilensis), with a consideration of organelle function. Aquaculture 107:175-183

Hine PM, Thorne T (1998) Haplosporidium sp. (Haplosporidia) in hatchery-reared pearl oysters, Pinctada maxima (Jameson, 1901), in north Western Australia. J Invertebr Pathol 71:48-52

> Hine PM, Thorne T (2002) Haplosporidium sp. (Alveolata: Haplosporidia) associated with mortalities among rock oysters Saccostrea cuccullata in north Western Australia. Dis Aquat Org 51:123-133

> Hine PM, Wesney B (1992) Interrelationships of cytoplasmic structures in Bonamia sp. (Haplosporidia) infecting oysters Tiostrea chilensis: an interpretation. Dis Aquat Org 14: $59-68$

Hine PM, Wesney B (1994) The functional cytology of Bonamia sp. (Haplosporidia) infecting oysters Tiostrea chilensis: an ultracytochemical study. Dis Aquat Org 20:207-217 
Hine PM, Cochennec-Laureau N, Berthe FCJ (2001) Bonamia exitiosus n. sp. (Haplosporidia) infecting flat oysters Ostrea chilensis in New Zealand. Dis Aquat Org 47:63-72

Hine PM, Wakefield S, Diggles BK, Webb VL, Maas EW (2002) Ultrastructure of a haplosporidian containing Rickettsiae, associated with mortalities among cultured paua Haliotis iris. Dis Aquat Org 49:207-219

Hine PM, Engelsma MY, Wakefield St J (2007) Ultrastructure of sporulation in Haplosporidium armoricanum. Dis Aquat Org 77:225-233

Kroeck MA, Montes J (2005) Occurrence of the haemocyte parasite Bonamia sp. in flat oysters Ostrea puelchana farmed in San Antonio Bay (Argentina). Dis Aquat Org 63:231-235

La Haye CA, Holland ND, McLean N (1984) Electron microscopic study of Haplosporidium comatulae n. sp. (Phylum Ascetospora: Class Stellatosporea), a haplosporidian endoparasite of an Australian crinoid, Oligometra serripinna (Phylum Echinodermata). Protistologica 20:507-515

López-Flores I, Suárez-Santiago VN, Longet D, Saulnier D, Chollet B, Arzul I (2007) Characterization of actin genes in Bonamia ostreae and their application to phylogeny of the Haplosporidia. Parasitology 134:1941-1948

Marchand J, Sprague V (1979) Ultrastructure de Minchinia cadomensis sp. n. (Haplosporida) parasite du décapode Rhithropanopeus harrisii tridentatus Maitland dans le canal de Caen à la mer (Calvados, France). J Protozool 26: 179-185

McGovern ER, Burreson EM (1990) Ultrastructure of Minchinia sp. spores from shipworms (Teredo spp.) in the western north Atlantic, with a discussion of taxonomy of the Haplosporidiidae. J Protozool 37:212-218

Newman MW, Johnson CA, Pauley GB (1976) A Minchinialike haplosporidan parasitizing blue crabs, Callinectes sapidus. J Invertebr Pathol 27:311-315

Nunan LM, Lightner DV, Pantoja CR, Stokes NA, Reece KS (2007) Characterization of a rediscovered haplosporidian parasite from cultured Penaeus vannamai. Dis Aquat Org 74:67-75

Ormières R (1980) Haplosporidium parisi n.sp. haplosporidie parasite de Serpula vermicularis L. étude ultrastructurale de la spore. Protistologica 16:467-474

Ormières R, de Puytorac P (1968) Ultrastructure des spores de l'Haplosporidie Haplosporidium ascidiarium endoparasite $\mathrm{du}$ Tunicier Sydnium elegans Giard. C R Acad Sci Paris Ser D 266:1134-1136

Perkins FO (1968) Fine structure of the oyster pathogen Minchinia nelsoni (Haplosporida, Haplosporidiidae). J Invertebr Pathol 10:287-307

Editorial responsibility: Stephen Feist, Weymouth, UK
Perkins FO (1969) Electron microscope studies of sporulation in the oyster pathogen, Minchinia costalis (Sporozoa: Haplosporida). J Parasitol 55:897-920

Perkins FO (1971) Sporulation in the trematode hyperparasite Urosporidium crescens de Turk, 1940 (Haplosporida: Haplosporidiidae) - an electron microscope study. J Parasitol 57:9-23

Perkins FO (1975) Fine structure of Minchinia sp. (Haplosporida) sporulation in the mud crab, Panopeus herbstii. Mar Fish Rev 37:46-60

Perkins FO (1979) Cell structure of shellfish pathogens and hyperparasites in the genera Minchinia, Urosporidium, Haplosporidium and Marteilia-taxonomic implications. Mar Fish Rev Jan-Feb: 25-37

Perkins FO (2000) Phylum Haplosporidia Caullery \& Mesnil, 1899. In: Lee JJ, Leedale GF, Bradbury P (eds) The illustrated guide to the Protozoa. Society of Protozoologists, Lawrence, KS, p 1329-1341

Pichot Y, Comps M, Deltreil JP (1980) Recherches sur Haplosporidium sp. (Haplosporida - Haplosporidiidae) parasite de l'huître plate Ostrea edulis. Rev Trav Inst Pêches Marit 43:405-408

> Reece KS, Stokes NA (2003) Molecular analysis of a haplosporidian parasite from cultured New Zealand abalone Haliotis iris. Dis Aquat Org 53:61-66

Reece KS, Burreson EM, Bower SM, Dungan CF (2000) Molecular analyses of a parasite in prawns (Pandalus platyceros) from British Columbia, Canada. J Shellfish Res 19: 647

Reece KS, Siddall ME, Stokes NA, Burreson EM (2004) Molecular phylogeny of the Haplosporidia based on two independent gene sequences. J Parasitol 90:1111-1122

Rosenfield A, Buchanan L, Chapman GB (1969) Comparison of the fine structure of spores of three species of Minchinia (Haplosporida, Haplosporidiidae). J Parasitol 55: 921-941

Sprague V (1979) Classification of the Haplosporidia. Mar Fish Rev 41:40-44

> Stentiford GD, Feist SW, Bateman KS, Hine PM (2004) Haemolymph parasite of the shore crab Carcinus maenas: pathology, ultrastructure and observations on crustacean haplosporidians. Dis Aquat Org 59:57-68

van Banning P (1977) Minchinia armoricana sp. nov. (Haplosporida), a parasite of the European flat oyster Ostrea edulis. J Invertebr Pathol 30:199-206

Vivarès CP, Brehélin M, Cousserans F, Bonami JR (1982) Mise en évidence d'une nouvelle Haplosporidie parasite de l'huître plate Ostrea edulis L. C R Acad Sci Paris Ser III 295:127-130

Submitted: July 21, 2008; Accepted: December 1, 2008 Proofs received from author(s): February 11, 2009 